\title{
OTOMATISASI SYSTEM PENCUCIAN MOBIL MENGGUNAKAN MIKROKONTROLER AT89C51
}

\author{
Halimatussa'diah \\ Fakultas Teknik Dan Ilmu Komputer, Program Studi Informatika \\ Universitas Indraprasta PGRI \\ Email: gbhock300679@gmail.com
}

\begin{abstract}
ABSTRAK
Banyaknya peralatan elektronika yang bekerja secara analog dan manual yang mempunyai kemampuan dan efektifitas yang rendah membuat orang berpikir untuk membuat peralatan elektronika yang mempunyai kemampuan dan keandalan yang tinggi. Salah satu contohnya adalah aplikasi pencucian mobil otomatis berbasis mikrokontroler. Pada kesempatan ini penulis mencoba merancang sistim kerja mesin pencucian mobil otomatis menggunakan mikrokontroler AT 89C51. Adapun tujuannya adalah untuk mengaplikasikan ilmu pengetahuan yang didapat kedalam bentuk nyata yaitu perancangan pembuatan suatu alat. Dengan batasan masalahnya yaitu perancangan dan pembuatan perangkat keras dan lunak dari mesin pencucian mobil otomatis yang menggunakan bahasa Assembly MCS-51, Mikrokontroler ATMEL 89C51, Motor Stepper penggerak belt conveyer. Metode penelitiannya adalah melakukan studi mengenai sistem mesin pencucian mobil otomatis menggunakan mikrokontroler dan rangkaian elektronika. Urutan dari sistematika penyajian adalah menyajikan latar belakang, tujuan penulisan, batasan masalah, dan diakhiri dengan sistematika pembahasan. Menyajikan gambaran tentang karakteristik dari mikrokontroler ATMEL AT89C51 yang merupakan komponen utama. Ini merupakan inti penulisan, tahap perancangan alat mulai dari tujuan, perancangan, percobaan perakitan sampai ketahap setelah dinyatakan alat berfungsi. Alat hasil rancangan akan diukur dan diuji secara keseluruhan untuk mengetahui karakteristik alat dan kendalanya yang akan diuraikan tentang prinsip kerja dan blok diagram rangkaian, rangkaian lengkap, perancangan alat, analisa rangkaian dan program komputer.
\end{abstract}

Kata kunci: efektifitas; assembly MCS-51, AT89C51; mikrokontroler; otomatis; karakteristik.

\begin{abstract}
The number of electronic devices that work in analog and manual that have low ability and effectiveness make people think to make electronics equipments that have ability and high reliability. One example is a microcontroller-based automated car wash application. On this occasion the author tries to design the automatic car washing machine work system using AT 89C51 microcontroller. The purpose is to apply the knowledge acquired into the real form of designing the making of a tool. With limitations of the problem is the design and manufacture of hardware and software of automated car washing machine using Assembly language MCS-51, ATMEL 89C51 Microcontroller, Stepper motor belt conveyer. The research method is to study the automatic car washing machine system using microcontroller and electronics circuit. The order of the presentation systematics is to present the background, the purpose of writing, the boundary of the problem, and end with the systematic discussion. Presents a picture of the characteristics of ATMEL AT89C51 microcontroller which is the main component. This is the essence of writing, the design stage of the tool ranging from goal, design, assembly experiment to phases after the tool is declared functioning. The design tool will be measured and tested in its entirety to determine the tool characteristics and constraints that will be described on the working principle and block circuit diagram, complete circuit, tool design, circuit analysis and computer program.
\end{abstract}

Keywords: effectiveness; assembly MCS-51; AT89C51; microcontroller; automatic; characteristics.

\section{PENDAHULUAN}

\subsection{Latar Belakang}

Dalam kehidupan manusia di dunia yang serba modern ini, banyak manusia menggunakan perangkat elektronika sebagai penunjang kebutuhan hidupnya. Dengan kemajuan elektronika maka dapat membantu mempermudah pekerjaan yang dilakukan oleh manusia. Banyaknya peralatan-peralatan elektronika yang bekerja secara analog dan manual yang mempunyai kemampuan dan efektifitas yang rendah membuat 
orang berpikir untuk membuat peralatan elektronika yang mempunyai kemampuan dan keandalan yang tinggi.

Penggunaan komputer sebagai perantara pengendali pada dasarnya untuk malaksanakan otomatisasi kerja pada perangkat yang dikendalikan. Salah satu contohnya adalah aplikasi pencucian mobil otomatis berbasis mikrokontroler. Berdasarkan pemikiran di atas, pada kesempatan ini penulis mencoba merancang sistim kerja mesin pencucian mobil otomatis menggunakan mikrokontroler AT 89C51, dimana penggunaan mikrokontroler sebagai komponen utama dikarenakan mikrokontroler mempunyai kemampuan menggerakkan alat atau sistem berdasarkan program yang dimasukkan ke dalam mikrokontroler tersebut.

Adapun tujuan penulisan adalah untuk mengaplikasikan ilmu pengetahuan yang didapat kedalam bentuk nyata yaitu perancangan pembuatan suatu alat. Disamping itu dengan membuat perancangan suatu alat penulis dituntut untuk dapat menyelesaikan suatu pokok permasalahan secara ilmiah dan dapat mempertanggungjawabkan hasil suatu pemikiran.

\subsection{Rumusan Masalah}

Dalam penulisan akan dibahas hal-hal yang berhubungan dengan proses pencucian mobil otomatis dan untuk membatasi masalah maka hanya dibahas hal-hal sebagai berikut:

a) Bagaimana merancang dan membuat perangkat keras dari mesin pencucian mobil otomatis.

b) Bagaimana merancang dan membuat perangkat lunak dari mesin pencucian mobil otomatis yang menggunakan bahasa assembly MCS-51.

c) Bagaimana alat utama mikrokontroler ATMEL 89C51 digunakan untuk pengendali dan pengontrol utama mesin pencucian mobil otomatis.

d) Bagaimana motor stepper digunakan untuk penggerak belt conveyer.

\section{METODOLOGI}

\subsection{Mikrokontroler ATMEL MCS-51}

\subsubsection{Dasar Pemilihan Mikrokontroler}

Bila sebuah mikroprosesor dikombinasikan dengan I/O dan memory (RAM dan ROM) akan dihasilkan sebuah mikrokontroler, dimana kombinasi dari komponen-komponen tersebut sudah terdapat dalam satu Chip Integrated Circuit [1]. Disebabkan mikrokontroler Sudah memiliki beberapa periferal di dalam chip IC, maka mikrokontroler mempunyai kelebihan dalam hal :

1) Ukuran sistem yang jauh lebih ringkas

2) Harga yang ekonomis

3) Kemudahan dalam merancang sistem yang berbasiskan Mikrokontroler.

4) Tingkat keamanan yang lebih dijamin.

5) Kehandalan yang lebih dijamin.

Kerugiannya adalah kemampuan sistem yang terbatas jika menggunakan mikrokontroler. Hal ini disebabkan karena adanya keterbatasan dari memori yang digunakan. Suatu aplikasi memiliki beberapa perbedaan dimana terdapat beberapa set instruksi pada mikrokontroler yang tidak sama dengan mikroprosesor. Set instruksi mikroprosesor bersifat processing intensive dalam bekerja dengan inputan kapasitas yang cukup besar, bekerja dengan cara nibble, byte and word. Berikut ini adalah kemampuan dari mikrokontroler AT89C51.

1) Kompatible dengan MCS 51

2) 8 Bit Mikrokontroler

3) 4 Kbytes In System Reprogrammable Flash Memory dengan kemampuan sampai 1000 kali pemrograman/penghapusan.

4) Range operasi $0-24 \mathrm{MHz}$

5) $128 \times 8$ Bit RAM

6) 32 Jalur I/O

7) Dua 16 Bit Timer/Counter

8) Enam sumber interupsi

9) On-Chip Oscillator dan Clock Cicuity

10) Programmable serial channel. 


\subsubsection{Organisasi Memori}

Organisasi memori pada mikrokontroler AT89C51 adalah sebagai berikut :

1. Memori Program

Mikrokontroler AT89C51 memiliki ruang memori program yang terpisah dengan memori data, ruang memori program dapat mencapai alamat hingga 4 Kbytes flash ROM (address $0000 \mathrm{H}$ sampai $0 \mathrm{FFFH}$ ).

2. Memori Data.

Memori data external pada mikrokontroler AT89C51 memiliki ruang hingga 64 kbytes, pengaksesan data ke memori data eksternal dilakukan dengan menggunakan data pointer melalui instruksi "MOV X". Disamping memiliki RAM external mikrokontroler AT 89C51 memiliki RAM internal yang pengaksesannya terpisah dengan RAM external, RAM internal AT89C51 berkapasitas 128 bytes ditambah dengan sejumlah SFR (Special Function Register), alamat terendah dari 128 bytes internal yang dapat diakses dengan mode pengalamatan langsung atau dengan pengalamatan tidak langsung, sedangkan special function register (SFR) hanya dapat diakses secara pengalamatan langsung. Dari 128 byte RAM internal yang dapat diakses secara pengalamatan langsung dan pengalamatan tidak langsung dapat dikelompokkan ke dalam 3 buah segmen alamat yaitu :

a) Register Bank 0-3, berlokasi mulai $00 \mathrm{H}$ sampai $1 \mathrm{FH}$ (32 bytes), masing-masing register bank memiliki 8 bytes register yaitu register 0 sampai register 7. Pada saat reset register bank default ke register bank 0 . Hal yang harus diperhatikan pada penggunaan register bank adalah saat setelah reset stack pointer menunjukkan ke alamat $07 \mathrm{H}$ pada internal RAM dan akan naik ke alamat $08 \mathrm{H}$ yang merupakan register pertama pada register bank kedua (R1), jadi jika program digunakan lebih dari satu register bank maka SP (stack pointer) harus diinisialisasi ke alamat yang lain dari RAM yang tidak digunakan untuk penyimpanan data.

b) Daerah pengalamatan per bit, beralamat antara $20 \mathrm{H}$ sampai dengan $2 \mathrm{FH}$ (16 bytes), masingmasing bit dari 128 bit yang terdapat pada segmen ini dapat diakses secara langsung (alamat 00H hingga alamat bit 7FH).

c) Sratch pada area, byte $30 \mathrm{H}$ hingga $7 \mathrm{FH}$ disediakan sebagai RAM data.

3. Special Function Register (SFR).

Register-register yang digunakan untuk pengelolaan program dan kendali komponen-komponen periferal internal tergabung didalam SFR, SFR menempati segmen alamat antara $80 \mathrm{H}$ sampai dengan alamat FFH di dalam RAM internal mikrokontroler AT89C51, register-register tersebut adalah :

a) Akumulator

Register akumulator seperti yang pernah disebut sebagai penyangga bagi data yang akan diperoleh dan sekaligus tempat transit bagi data yang akan dan telah selesai diolah oleh bagian logika dan aritmatika.

b) Register $\mathrm{B}$

Register B digunakan selama operasi perkalian dan pembagian data yang akan dikalikan/dibagikan disimpan pada akumulator dan register B, dan hasilnya disimpan pada akumulator dan register $\mathrm{B}$.

c) Program Status Word (PSW)

PSW sebagai register yang berisi data-data kondisi mikrokontroler setelah suatu operasi selesai dijalankan, register PSW memiliki lebar 8 bit, dimana bit ke-3 dan ke-4 digunakan untuk pemilihan register bank

d) Stack Pointer (SP)

Register SP berisi alamat stack tertinggi dari lokasi stack di dalam internal RAM, register ini berguna untuk menyimpan alamat-alamat data yang ditandai pada saat terjadi pemanggilan sub program dan interupsi program.

e) Data Pointer (DPTR)

Register DPTR merupakan register 16 bit DPH dan DPL, DPH berisi alamat tinggi dan DPL berisi alamat rendah dari data RAM external. Semua pengaksesan data ke RAM external alamatnya ditunjuk melalui register DPTR.

f) Register Port

Register Port ada 4 yaitu register P0, P1, P2 dan P3. Register port berisi data-data yang akan dikirim ke luar dan data-data yang telah dibaca dari luar.

g) Register Buffer Data Serial (SBUF) 
Register SBUF terdiri atas dua yaitu register buffer kirim dan register buffer terima, yang masing-masing digunakan sebagai buffer bagi data yang akan dikirim serial dan data yang akan diterima secara serial pula.

h) Register Pewaktu.

Register pewaktu digunakan untuk menyimpan data offset yang akan digunakan untuk membatasi perhitungan waktu, pewaktu yang terdapat pada mikrokontroler AT89C51 adalah pewaktu 16 bit sebanyak 2 buah, maka terdapat 2 buah register pewaktu yang dibentuk dari pasangan-pasangan register 8 bit, yaitu TH0 dan TL0 dengan TH1 dan TL1.

i) Register-register Kendali

Register IP (Interrupt Priority) merupakan register pengatur level prioritas pada mikrokontroler AT89C51 yaitu pewaktu interupsi TF0 dan TF1, external interupsi INT0 dan INT1 dan serial port interupsi T1 dan R1, tingkatan prioritas interupsi dari keenam buah interupsi tersebut dapat diatur sesuai dengan keperluan.

j) Register IE (Interrupt Enable) merupakan register yang digunakan untuk mengatur keaktifan sistem interupsi, melalui register ini interupsi-interupsi dapat diaktifkan dan dinonaktifkan

k) Register TMOD (Timer MODe) merupakan register yang berfungsi mengatur mode kerja dan keaktifan serta fungsi (sebagai pewaktu atau sebagai pencacah) pada kedua pewaktu yang ada pada mikrokontroler AT89C51.

1) Register TCON (Timer CONtrol) adalah register yang digunakan untuk mengatur keaktifan dan juga berisi flag-flag yang menunjukkan keaktifan interupsi pewaktu, disamping itu register TCON juga digunakan untuk mengatur keaktifan dari mode interupsi external dan berisi flag-flag yang menunjukkan keaktifan interupsi internal.

m) Register SCON (Serial CONtrol) merupakan register yang mengatur keaktifan, mode dan format data dari sistem komunikasi serial antara mikrokontroler AT89C51 dengan lingkungannya.

\subsubsection{Struktur Port}

Keempat buah port AT89C51 masing-masing terdiri dari 8 jalur port bi-directional (biasa digunakan sebagai masukan dan keluaran). Masing-masing jalur port tersebut terdiri dari latch, output driver, dan input buffer. Output buffer dari port 0 dan 2, dan input buffer dari port 0 digunakan untuk mengakses memori external. Output Port 0 adalah alamat bagian bawah memori external yang dimultipleks dengan data yang akan ditulis atau dibaca. Output port 2 adalah alamat bagian atas dari memori external. Namun bila tidak dipakai ruang memori program external, maka kedua port tersebut langsung dapat dipakai sebagai port input atau output. Semua pin port 3 mempunyai fungsi lain dari luar port, fungsi yang dimaksud adalah sebagai berikut :

a) P3.0 : Port input serial, $\mathrm{RxD}$

b) P3.1: Port output serial, Txd.

c) P3.2 : Input interupsi external, INT0

d) P3.3 : Input interupsi external, INT1

e) P3.4 : Input external untuk pewaktu/pencacah 0, T0

f) P3.5: Input external untuk pewaktu/pencacah 1, T1

g) P3.6 : Sinyal tulis memori external aktif low, WR

h) P3.7 : Sinyal baca memori external aktif low, RD

Konfigurasi bagian port yang terdiri dari latch, buffer I/O. Latch yang dipakai dapat diaplikasikan dengan flip-flop D. Data dari bus internal di latch saat CPU mengarahkan pada sinyal text ke latch, dan hasil keluaran latch diberikan ke bus internal saat CPU memberi sinyal baca ke latch. Data pada pin diberikan ke bus internal sebagai respon terhadap sinyal baca pin dari CPU. Beberapa instruksi yang berfungsi membaca port mengaktifkan sinyal baca latch dan yang lain mengaktifkan sinyal baca pin.

Port 1, 2, 3 memiliki internal pull up, port 0 dengan open drain output. Di setiap jalur I/O bias di pakai masing-masing sebagai input-output. Jika dipakai sebagai input, port latch harus berisi 1 . Untuk port 1, 2, dan 3 pin akan di-pull up tinggi oleh pull up internal, dan juga di-pull up rendah oleh sumber external.

Port 0 tidak memiliki pull up internal. Pull up FET itu bisa di pakai jika ada akses external memori. Port akan berfungsi sebagai input berfrekuensi tinggi bila latch diisi 1 dan akan bersifat open drain bila sebagai output. 


\subsection{Metode Pengalamatan}

Metode pengalamatan pada AT89C51 adalah sebagai berikut :

a) Pengalamatan Langsung (Direct Addressing)

Pada pengalamatan langsung, dalam perintahnya operand di arahkan pada suatu alamat yang lebarnya 8 bit, dan hanya bisa digunakan untuk data internal RAM dan SFR. MOV A, direct (pindahkan langsung dari byte tertentu ke akumulator)

b) Pengalamatan Tidak Langsung (Indirect Addressing).

Pada pengalamatan tidak langsung, perintah mengarahkan pada register yang di dalamnya terdapat alamat dari operand.

External dan Internal RAM dapat dialamati secara tidak langsung. Register alamat untuk alamat dengan lebar 8 bit bisa berupa R0 dan R1 yang digunakan untuk memilih register bank atau Stack Pointer. Register alamat untuk alamat dengan lebar 16 bit digunakan data pointer DPTR.

MOV A, @Ri (Pindahkan Indirect RAM ke akumulator).

c) Pengalamatan Berindeks (Indexed Addressing)

Yang dapat diakses dengan pengalamatan berindeks hanya memori program. Mode ini dimaksudkan untuk membaca look up table di memori program. MOVC A,@ A+PC (Pindahkan kode byte relatif program counter ke akumulator). MOVC A, @ A+DPTR (Pindahkan kode byte relatif relatif DPTR ke akumulator)

d) Pengalamatan segera (Immediate Addressing).

Dalam memori program suatu opcode dapat langsung diikuti oleh suatu konstanta, sebagai contoh :

MOV A,\#16 : isi akumulator dengan decimal 16, Bila digunakan bilangan heksadesimal, hasilnya tetap sama yaitu MOV A,\#0FH [2].

\subsubsection{Diagram Blok dan Cara Kerja}

Tahap selanjutnya dalam perancangan suatu alat adalah membuat suatu diagram blok, dimana diagram blok ini berfungsi untuk mempermudah didalam memahami rangkaian dan perakitan alat. Dengan demikian dalam tahap perancangan dan perakitan alat akan dibuat berdasarkan per-blok diagram rangkaian, masing-masing blok memiliki kegunaan yang saling berhubungan antara satu dan lainnya pada setiap rangkaian. Adapun diagram blok rangkaian yang dimaksud ditampilkan pada gambar 1 .

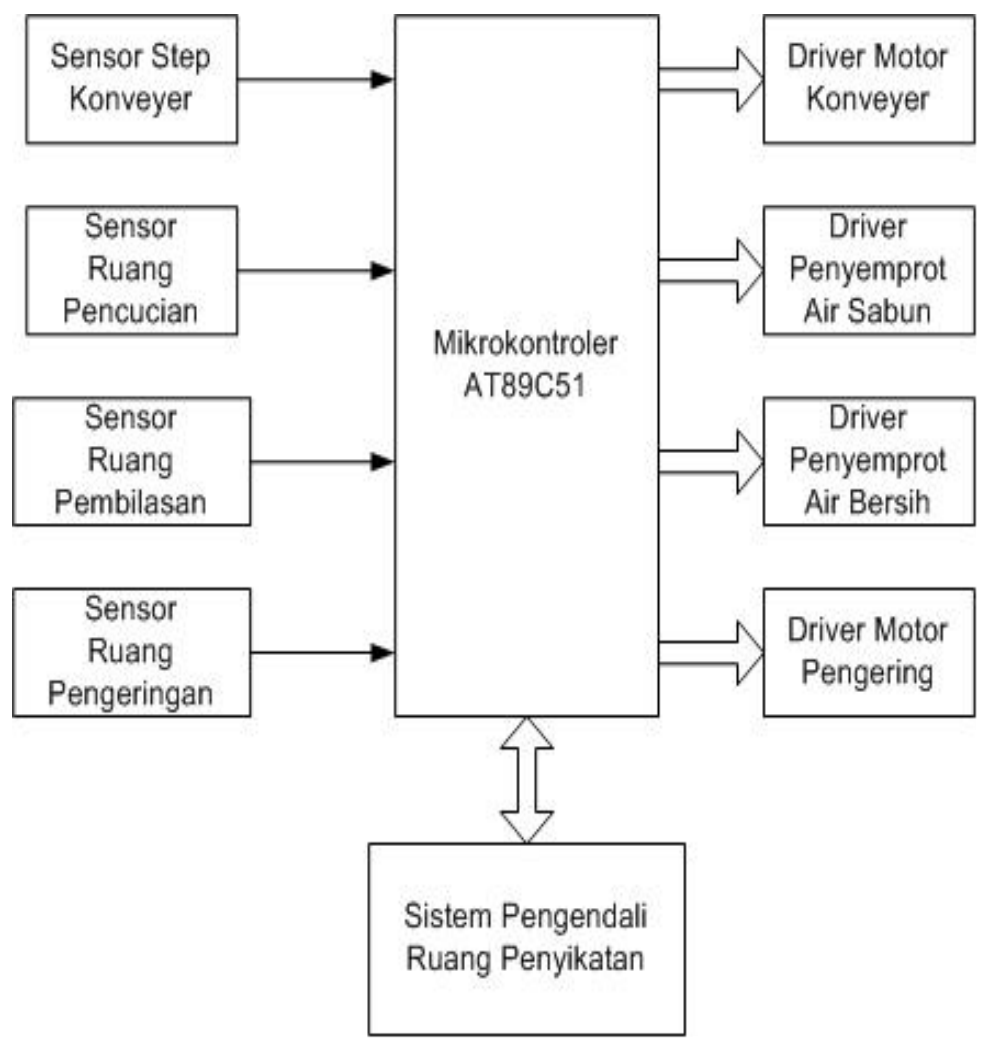

Gambar 1. Blok Diagram Sistim 
Prinsip kerja alat adalah sebagai berikut : Pada alat ini terdapat 4 penempatan sensor photodioda, dimana masing-masing penempatannya digunakan untuk melakukan tugas yang berbeda. Penempatan photodiode yang pertama pada pintu masuk yang gunanya untuk mengaktifkan penyemprotan air sabun, photodiode kedua pada ruang penyikatan yang digunakan bersama sama oleh dua mikrokontroler yaitu mikrokontroler pengendali konveyer dan mikrokontroler pengendali ruang penyikatan. Photodiode ketiga digunakan untuk mengendalikan penyemprotan air bersih. Terakhir adalah photodioda yang keempat digunakan untuk menggerakan fan yang berfungsi sebagai pengering. Proses kerja sistim otomatisasi ini diawali dengan pembacaan tombol start pada saat pencucian akan dimulai. Ketika tombol start diaktifkan maka mikrokontroler bekerja. Mikrokontroler akan menggerakan Belt-conveyor (ban berjalan) untuk menggerakan kendaraan yang terlebih dahulu dimatikan mesinnya sampai sensor photodioda yang terpasang di pintu masuk akan terhalang kendaraan bagian depan [3].

Proses selanjutnya, jika mikrokontroler mendeteksi adanya kendaraan pada ruang penyemprotan mikrokontroler melakukan proses penyemprotan air sabun yang disimulasikan dengan running led sampai sensor ruang penyemprotan kembali ke kondisi idle.

Setelah proses pada ruang pertama selesai dan sensor pada ruang penyikatan dalam kondisi aktif mikrokontroler akan menginterupsi mikrokontroler pengendali ruang penyikatan untuk me-load kembali data hasil sampling diselingi dengan menggerakkan konveyer sebanyak 5 langkah. Begitu proses ini dilakukan berulang-ulang sampai pada ketinggian terakhir kendaraan.

Pada proses penyikatan mikrokontroler akan menggerakkan konveyer enam langkah kemudian berhenti. Pada saat berhenti ini mikrokontroler menginstruksikan pengendali ruang penyikatan untuk melakukan tugasnya yaitu melakukan proses pembacaan tinggi kendaraan dan penyikatan. Proses ini dilakukan terus menerus sampai kendaraan meninggalkan ruang penyikatan.

Proses selanjutnya adalah proses pembilasan dan proses pengeringan. Proses - proses tersebut dilakukan dengan tetap menggerakkan konveyer. Proses pembilasan dilakukan jika sensor photodiode yang ada di ruang pembilasan terhalang kendaraan. Proses ini diawali dengan menonatifkan proses sebelumnya kemudian mengaktifkan running led kedua yang merupakan simulasi air pembilas. Setelah proses pembilasan selesai proses berikutnya adalah proses pengeringan yang ditandai dengan terhalangnya sensor photodiode di ruang pengeringan. Tahap ini merupakan proses terakhir dengan berputarnya fan pengering yang dilakukan oleh mikrokontroler master. Setelah semua tahapan dalam car wash system selesai semua buffer dan actuator kembali pada kondisi awal untuk proses pencucian

\subsubsection{Rangkaian Simulasi Penyemprot}

Rangkaian simulasi tersebut digunakan hanya sebagai simulasi dari penyemprotan air sabun dan air pembersih [5]. Pada gambar 2.2.2. A, B di bawah adalah rangkaian penyemprot yang digunakan. Masingmasing rangkaian terdiri dari 10 buah LED yang diumpamakan sebagai penyemprot air, 10 buah dioda, IC 4017, serta 5 buah transistor yang berfungsi sebagai saklar untuk mengaktifkan LED yang dirangkai parallel.

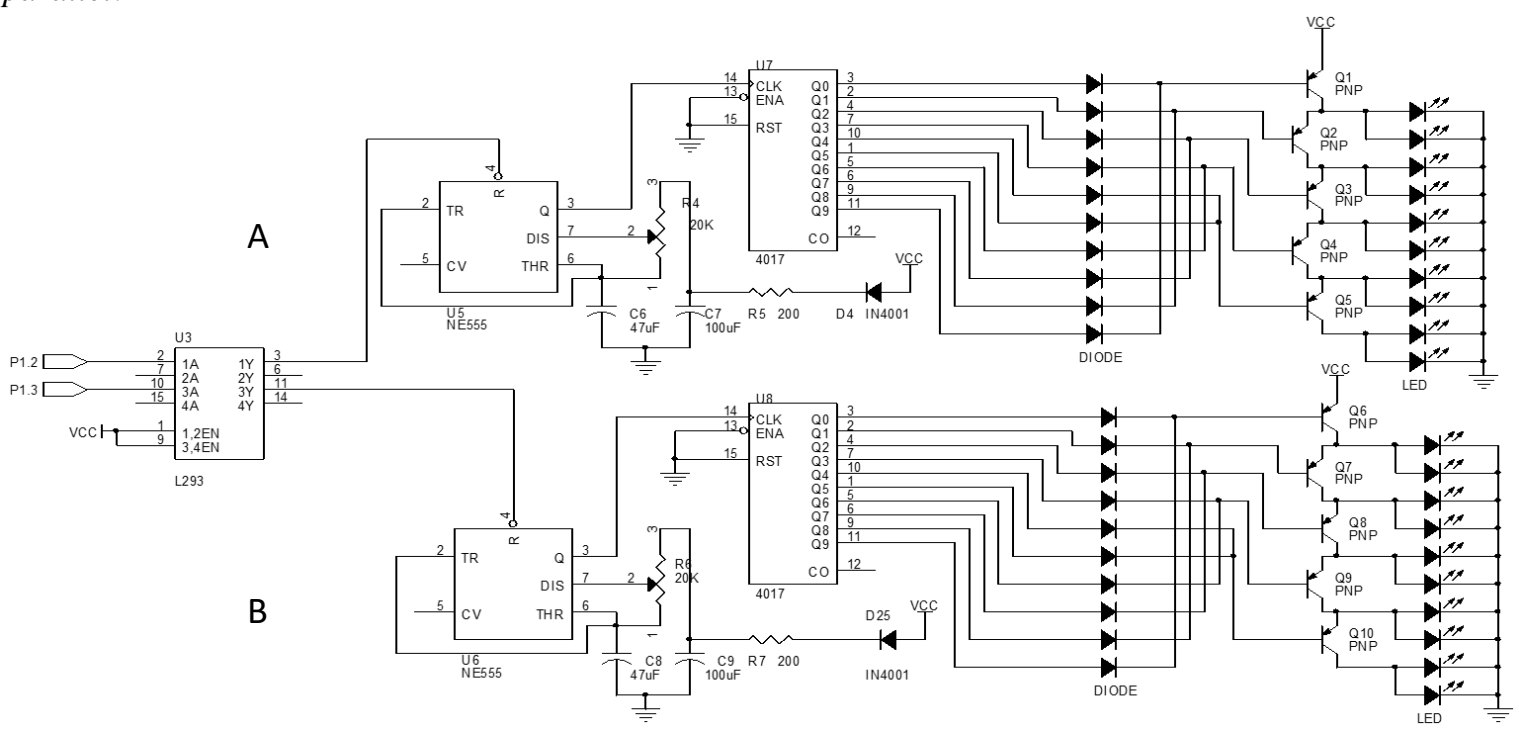

Gambar 2. A, B. Rangkaian Simulasi Penyemprotan 
Gambar 2 rangkaian A adalah simulasi untuk penyemprotan air bersih dan B adalah simulasi untuk rangkaian penyemprotan air sabun. Kedua rangkaian tersebut membutuhkan tegangan 5 Volt untuk mengaktifkan IC 4017.

Pada rangkaian diatas apabila pin 1A mendapat tegangan 5 Volt maka IC 4017 akan aktif dan dan pin $1 \mathrm{Y}$ akan mengeluarkan tegangan sebesar 12 Volt, dan akan mengaktifkan penyemprot air. Apabila pin 1A mendapat tegangan 0 Volt maka pin $1 \mathrm{Y}$ akan mendapat tegangan 0 Volt. Rangkaian ini bekerja secara bergantian yaitu apabila rangkaian penyemprotan air sabun telah selesai maka maka secara otomatis rangkaian penyemprot air bersih (rangkaian A ) akan bekerja dan rangkaian pemyemprot air sabun akan berhenti.

\subsubsection{Perancangan Software}

Apabila perangkat kerasnya sudah di aplikasikan, untuk selanjutnya bisa mengaplikasikan software nya yang bisa bekerjasama dengan perangkat keras dalam hal ini hardware, sebab tanpa adanya software atau perangakat lunak maka hardware tidak dapat berfungsi sebagaimana mestinya, maka perangkat lunak adalah pola pikir dari hardware yang sangat penting.

Untuk membuat software, listing program diaplikasikan melalui sistem prosedur dimana setiap prosedur memiliki kegunaan tertentu dan secara merata prosedur membuat sistem dari program yang diharapkan. Langkah awal dalam membuat listing program adalah membuat diagram alur atau flowchart sebagai acuan dasar dalam membuat program. Kemudian setiap fungsi dari flowchart tersebut dibuat listing programnya.

Adapun untuk membuat listing program dapat menggunakan bahasa assembler yang khusus untuk keluarga mikrokontroler MCS-51, dengan bantuan program khusus misalnya ASEM-51 yang sudah terkenal. Listing program dibuat dengan Word atau notepad kemudian dikompilasi oleh ASEM-51 sehingga berekstensi OBJ dan terakhir dikompilasi kembali sehingga berekstensi HEX. File yang berekstensi HEX inilah yang akan dimasukkan ke mikrokontroler AT89C51.

Adapun sistem pengisian dapat dilakukan oleh program pengisi yang ada pada program ASEM-51 juga dan dengan bantuan alat khusus yang tersedia dipasaran atau dengan meminta bantuan pada toko elektronika khusus untuk mengisi program pada mikrokontroler.

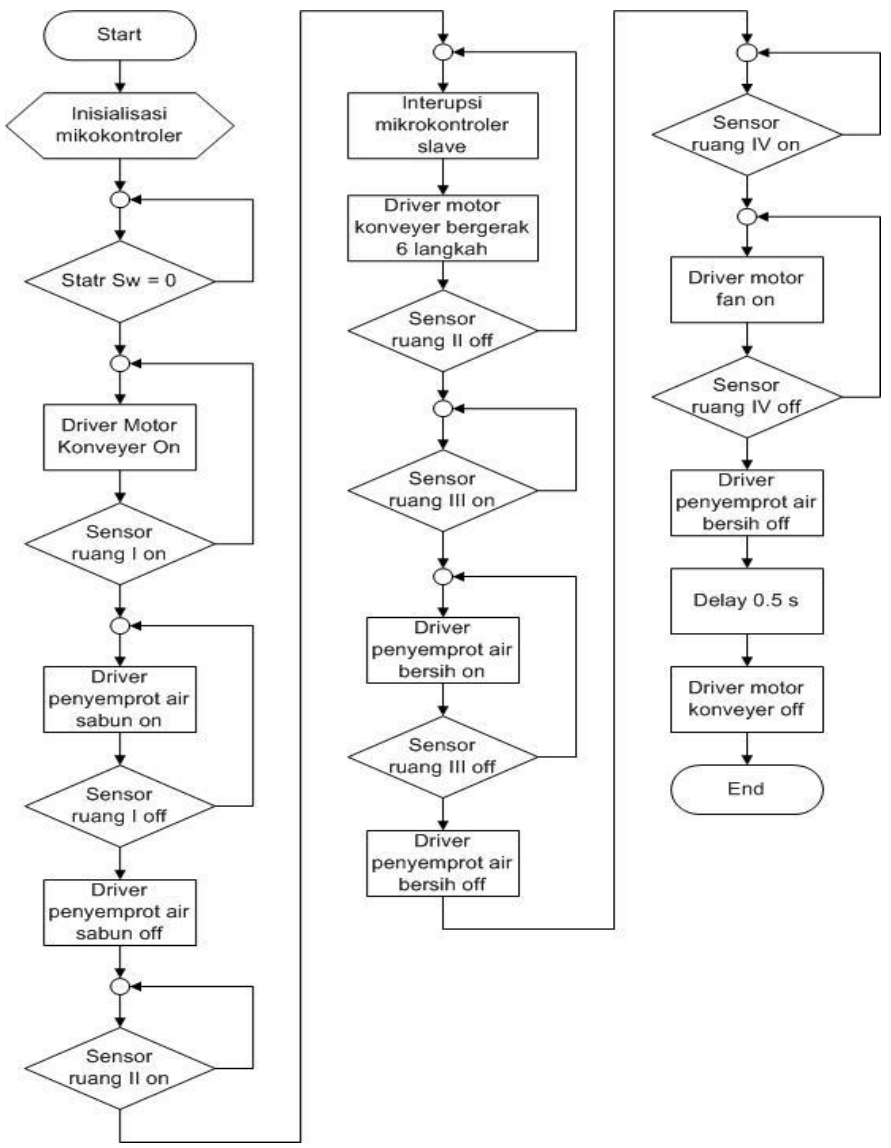

Gambar 3. Flowchart Mikrokontroler 
Keterangan gambar 3 flowchart mikrokontroler master adalah sebagai berikut : Proses inisialisasi adalah proses mengkondisikan mikrokontroler untuk siap bekerja [4]. Pada proses ini yang perlu diperhatikan untuk menset kondisi awal register - register internal mikrokontroler dan input output-nya.

Kemudian mikrokontroler akan mengecek kondisi pin Start switch pada pin P0.4. Jika pada pin ini terdeteksi logika 1 maka mikrokontroler akan melakukan looping sampai kondisi pin ini berubah menjadi berlogika 0 . Jika logika 0 terdeteksi pada pin ini mikrokontroler akan mengirim data 1 ke pin P1.0 untuk menggerakkan motor DC penggerak konveyer.

Pada proses selanjutnya mikrokontroler akan menunggu perubahan logika pada pin P0.1 berubah dari logika 0 menjadi logika 1 dimana pin ini digunakan untuk memantau apakah kendaraan sudah sampai ruang penyiraman air sabun atau belum. Logika 1 manandakan bahwa kendaraan sudah sampai pada ruang penyiraman air sabun. Jika pada pin ini berlogika 1 mikrokontroler akan mengirimkan data melalui pin P1.2 untuk menyemprotkan air sabun dengan merubah logika dari 0 menjadi 1. Proses penyemprotan air sabun ini akan bertahan sampai pin P0.1 berubah logika dari 1 menjadi 0 .

Proses pada ruang penyikatan dipantau mikrokontroler melalui P0.2. Jika logika berubah dari 0 menjadi 1 maka mikrokontroler akan mengirim perintah ke pengendali ruang penyikatan untuk melakukan tugasnya. Pada proses ini mikrokontroler akan mengontrol gerakan konveyer melalui pin P0.0. Selama P0.2 berlogika 1 konveyer akan bergerak 6 langkah kemudian diam. Pada saat ini mikrokontroler kembali menginstruksi pengendali ruang penyikatan untuk melakukan tugasnya dengan mengirim logika 1 melalui pin P3.1.

Pada proses penyiraman air bersih ini mikrokontroler memantau kondisi dari pin P0.3. Jika logika berubah dari 0 menjadi 1 maka mikrokontroler akan mengaktifkan penyemprot air bersih dengan memberi logika 1 pada pin P1.3 sampai pin P0.3 kembali berlogika 0 .

Proses terakhir pada mikrokontroler adalah proses pengeringan. Hal ini dilakukan mikrokontroler dengan memberikan logika 1 pada motor penggerak fan yaitu pin P1.1 selama P0.3 berubah logikanya dari 0 menjadi 1.

\section{HASIL DAN PEMBAHASAN}

Setelah melakukan perancangan dan pembuatan alat maka langkah berikutnya adalah melakukan pengukuran pada blok blok yang perlu. Pengukuran dalam hal ini diperlukan alat bantu multimeter digital.

\subsection{Prosedur Ujicoba}

Setelah perancangan dan pemahaman alat selesai, maka langkah selanjutnya adalah pengukuran dan analisa system. Hal ini dilakukan untuk lebih memahami dan mengetahui karakteristik setiap blok rangkaian sampai fungsi alat secara keseluruhan. Dengan demikian dapat kita bandingkan antara perancangan dan alat yang telah dibuat.

\subsubsection{Setup Alat}

Setup alat merupakan rancangan pertam kali supaya alat dapat berfungsi dengan maksimal. Dalam penulisan tugas akhir ini dilakukan langkah-langkah setup alat sebagai berikut :

a) Photodiode.

Sensor photodiode berfungsi sebagai penerima sinyal berupa pancaran sinar yang dikeluarkan oleh infrared, yang nantinya akan menjadi input bagi Mikrokontroller untuk pengerjaan suatu task.

b) Mikrokontroller AT89C51

Mikrokontroller AT89C51 ini adalah salah satu bagian dari MCS yang mempunyai pin berjumlah 40, namun saya cukup menjabarkan pin-pin yang difungsikan untuk pembuatan alat, dimana setiap port-port pada mikrokontroler mempuyai kegunaan/kendali khusus. Hampir semua port pada mikrokontroller bisa difungsikan menjadi input dan output. Untuk lebih jelasnya, dibawah ini akan di paparkan kegunaan dari tiap-tiap port mikrokontroller.

\subsubsection{Upload Software}

Apabila sudah dapat membuat rancangan dan pembentukkan alat, maka langah berikutnya yaitu menyusun program pengendali alat yang terdapat pada system ini. Program pengendalian ini bertujuan untuk mengarahkan langkah-langkah kerja pada tiap-tiap rangkaian.

Setiap pengenadali yang disusun berbasis pengendali controller, sebab pengendalian ini di buat melalui ATMEL 89C51. Bahasa pemrograman yang diaplikasikan sebagai pengarah program alat ini 
adalah bahasa pemrograman assembler. Adapun langkah-langkah upload software yang dilakukan agar program pengendali tersebut dapat berfungsi sebagaimana mestinya adalah sebagai berikut :

a) Hidupkan komputer dan masukan pada system assembler.

b) Susunan pembuatan program harus sesuai dengan flowchart sebagai alur pengatur.

c) Jika pembuatan program selesai, maka jalankan program sesuai dengan perintah.

d) Apabila tidak ditemukan masalah pada program, lakukan penyimpanan program ke mikrokontroller.

e) Tutup program dan lakukan pengecekan pada IC tersebut.

f) Lakukan uji coba terhadap alat, apakah sesuai dengan perancangan yang disusun atau belum. Jika belum, lakukan pengecekan pada alur program atau rubah program sampai kerja alat sempurna.

\subsubsection{Tujuan}

Tujuan dari pengukuran system pengaturan otomatisasi pencucian mobil berbasis mikrokontroller AT89C51 adalah untuk :

a) Mengetahui, apakah perangkat kerasnya dapat bekerja dengan baik atau tidak.

b) Melakukan pengambilan data untuk mendapatkan hasil kerja yang optimal.

c) Menarik kesimpulan dari seluruh proses kerja perangkat keras system tersebut secara otomatis.

Sebelum melakukan pengukuran dan analisa pada tugas akhir ini, maka dilakukan prosedur kerja untuk mendapatkan hasil pengukuran yang akurat dan sempurna. Terlebih dahulu dipersiapkan hal-hal sebagai berikut :

1) Pengukuran diatur dengan mengukur bagian-bagian pada setiap blok-blok rangkaian.dalam hal ini dilakukan beberapa kali agar mendapatkan hasil yang benar.

2) Komponen yang digunakan .

a) IC mikrokontroller AT89C51.

b) Regulator 7805 dan 7812

c) Photodiode

d) Infrared

3) Alat ukur

a) Multitester digital

\subsection{Pengukuran Catu Daya}

Rangkaian catu daya adalah hal pertama yang harus mendapat perhatian mengingat catu daya merupakan sumber daya alat sehingga jika catu daya tidak bekerja maka alat pun tidak akan bekerja. Pengukuran dilakukan berulang - ulang dengan tujuan untuk meyakinkan apakah data yang diukur telah memenuhi standar rangkaiaan atau tidak [6]. Berdasarkan pengukuran diperoleh data yang ditunjukkan pada tabel 1 dan tabel 2 .

Tabel 1. Hasil akhir tegangan output catu daya 5 VDC

\begin{tabular}{cc}
\hline Pengukuran & Vout 5 VDC \\
\hline 1 & 4,9 \\
2 & 4,9 \\
3 & 4,9 \\
4 & 4,9 \\
5 & 4,9 \\
\hline
\end{tabular}


Hasil akhir keluaran tegangan pada pengukuran catu daya sudah sesuai dengan perancangan yaitu sekitar 5 VDC walaupun hasil akhirnya tegangan tidak murni bernilai $5 \mathrm{~V}$, namun sudah bisa untuk digunakan.

\begin{tabular}{cc} 
Table 2. Hasil akhir tegangan output catu daya 12 VDC \\
\hline Pengukuran & Vout 12 VDC \\
\hline 1 & 11,8 \\
2 & 11,8 \\
3 & 11,8 \\
4 & 11,8 \\
5 & 11,8 \\
\hline
\end{tabular}

Hasil akhir keluaran tegangan pada pengukuran catu daya sudah sesuai dengan perancangan yaitu sekitar 12 VDC walaupun hasil akhirnya tegangan tidak murni bernilai $12 \mathrm{~V}$, namun sudah bisa untuk digunakan.

\subsection{Pengukuran pada Photodioda}

Pada alat ini digunakan photodiode untuk menerima sinyal berupa pancaran sinyal dari infrared. Fungsi dari kedua blok rangkaian tersebut adalah sebagai pengukur ketinggian pada kendaraan yang akan memasuki ruang pencucian. Penempatan sensor tersebut terletak ditiga bagian dengan prosedur pengerjaan output yang berbeda seperti yang telah dijelaskan pada bab sebelumya.

Pengamatan dilakukan dengan cara yang sama dengan pengamatan catu daya. Pada saat photodiode terhalang, maka akan diperoleh output tegangan. Begitu juga ketika photodiode tidak terhalang dan tentu saja tegangan tersebut berbeda dengan tegangan yang diperoleh pada saat photodiode tersebut terhalang oleh benda. Hasil pengukuran output tegangan photodioda ditunjukkan pada tabel 3.

Table 3. Hasil pengukuran output tegangan photodioda

\begin{tabular}{ccc}
\hline Pengukuran & Vout terhalang & Vout tidak terhalang \\
\hline 1 & $4,6 \mathrm{~V}$ & $0,1 \mathrm{~V}$ \\
2 & $4,5 \mathrm{~V}$ & $0.1 \mathrm{~V}$ \\
3 & $4,7 \mathrm{~V}$ & $0,1 \mathrm{~V}$ \\
4 & $4,6 \mathrm{~V}$ & $0,1 \mathrm{~V}$ \\
5 & $4,6 \mathrm{~V}$ & $0,1 \mathrm{~V}$ \\
\hline
\end{tabular}

Disamping pengukuran tegangan, pada output juga disimulasikan dengan led. Pada saat photodiode terhalang led akan padam sedangkan pada saat photodiode tidak terhalang led akan menyala. Dengan Vout seperti pada table diatas dapat disimpulkan bahwa rangkaian photodiode tersebut bekerja sesuai dengan yang diinginkan, karena tegangan output tersebut sesuai dengan level TTL. Rangkaian Lengkap Otomatisasi System Pencucian Mobil Menggunakan Mikrokontroler AT89C51 ditunjukkan pada gambar 4. 


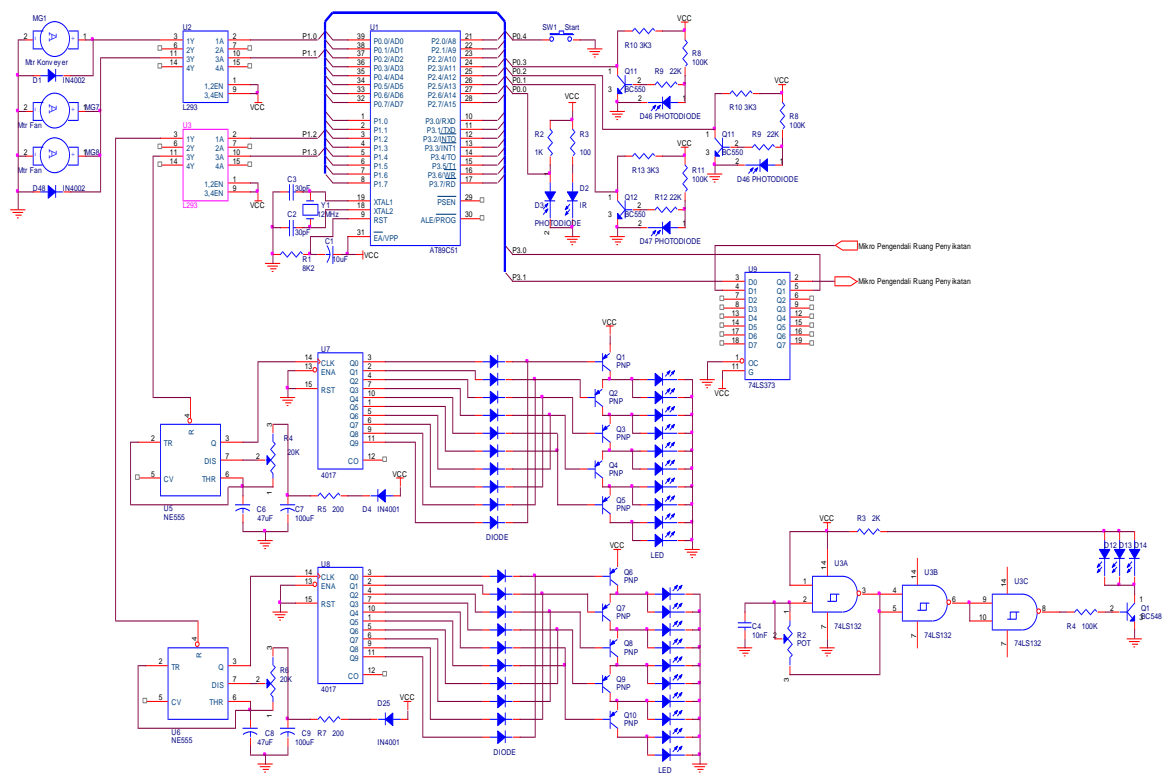

Gambar 4. Rangkaian Lengkap Otomatisasi System Pencucian Mobil Menggunakan Mikrokontroler AT89C51

\section{KESIMPULAN}

Dari hasil yang diperoleh dan analisa terhadap sistem dapat ditarik beberapa kesimpulan, yaitu :

a) Penggunaan mikrokontroler adalah untuk mengontrol dan juga memberi command ke masing masing port, baik itu port masukan ataupun port keluaran. Dari pengujian sistem secara lengkap dengan menggunakan program yang tersimpan di dalam mikrokontroler, didapatkan hasil berupa putaran motor yang dapat dikontrol. Dengan memilih mikrokontroller at89c51 dengan membuat metode pengalamatan dalam perancangan suatu alat adalah membuat suatu diagram blok, dimana diagram blok ini berfungsi untuk mempermudah didalam memahami rangkaian dan perakitan alat. Dengan demikian dalam tahap perancangan dan perakitan alat akan dibuat berdasarkan per-blok diagram rangkaian, masing-masing blok memiliki kegunaan yang saling berhubungan antara satu dan lainnya pada setiap rangkaian.

b) Software yang digunakan adalah bahasa assembler dimana program ini dapat dijalankan secara otomatis dan dapat menjalankan sistem sesuai dengan yang kita inginkan berdasarkan dengan listing program yang telah kita buat. Sedang perancangan software listing program dengan menggunakan bahasa assembler yang khusus untuk keluarga mikrokontroler MCS-51 dibuat dengan sistem prosedur dimana masing-masing prosedur memiliki kegunaan tertentu dan secara merata prosedur membuat sistem dari program yang diharapkan. Langkah awal dalam membuat listing program adalah membuat diagram alur atau flowchart sebagai acuan dasar dalam membuat program. Kemudian setiap fungsi dari flowchart tersebut dibuat listing programnya. Setelah perancangan baru dilakukan upload software secara keseluruhan.

c) Rangkaian simulasi penyemprotan digunakan hanya sebagai simulasi dari penyemprotan air sabun dan air pembersih, dimana Masing-masing rangkaian terdiri dari 10 buah LED yang diumpamakan sebagai penyemprot air, 10 buah dioda, IC 4017, serta 5 buah transistor yang berfungsi sebagai saklar untuk mengaktifkan LED yang dirangkai parallel. Rangkaian ini bekerja secara bergantian yaitu apabila rangkaian penyemprotan air sabun telah selesai maka maka secara otomatis rangkaian penyemprot air bersih (rangkaian A ) akan bekerja dan rangkaian pemyemprot air sabun akan berhenti.

d) Alat ini berjalan sesuai dengan input yang yang diberikan yaitu apabila ada obyek yang berjalan maka sensor akan memberi input kepada mikrokontroler untuk menjalankan program penyemprot air. Disini program kontrol akan menjalan fungsinya kemudian akan memberi input pada mikro untuk melakukan penyikatan. Secara garis besarnya dapat disimpulkan bahwa mikro pada system pencucian mobil tersebut dapat berjalan secara baik berdasarkan program yang telah upload kan pada mikro tersebut, sedang kekurangannya adalah masih sering terjadi error pada alat apabila salah satu komponen pendukungnya tidak bekerja. 


\section{DAFTAR PUSTAKA}

[1] Kurniawan, F. April 2009. “Implementasi Mikrokontroler Sebagai Pencacah Berbasis Pengukuran Periode Isyarat Masukan” Telkomnika Vol. 7, No. 1.

[2] Wardoyo, S. November 2011. "Dasar Mikroprosessor" Buku Ajar Universitas Sultan Ageng Tirtayasa.

[3] Anindita, A., Sudjadi., \& Darjat. 2013 "Sistem Informasi Area Parkir Berbasis Mikrokontroler ATMEGA 16" TRANSMISI.

[4] Zulfikar., Tarmizi., Agus Andria. April 2011 "Perancangan Pengontrolan Traffic Light Otomatis"Jurnal Rekayasa ElektrikaVol. 9, No. 3.

[5] Fathan, M Syuaib., Amalia, F Zahrina., Syufrijal. Juni 2017 "Prototipe Sistem Pencucian Mobil Otomatis Berbasis PLC" JUrnal Auto Cracy, Vol.4, no.1.

[6] Syafarudin, F., Anto, B. Oktober 2017 "Rancang Bangun Saklar Pemindah Otomatis Berpenggerak Motor Stepper Variable Reluctance Dengan Pengendali Mikrokontroler ATMega8535" Jom FTEKNIK Volume 4 no. 2 